\title{
Importance of Recreational Instrumental Music- Making in Development of Personal Aesthetic Culture
}

\author{
Kamalova G.R. \\ Kazan State Institute of Culture \\ Kazan,Russia \\ gulnurrk88@mail.ru
}

\begin{abstract}
The purpose of this work is theoretical and practical study of the method of recreational music use making in the development of personal aesthetic culture. Scientific literature analysis in the sphere of aesthetic culture development revealed the key components of given phenomenon and the most successful forms of its development supporting the purpose of the research achievement. So, creative and musical activity components in our opinion in the best way develop in cultural and recreational programme of instrumental music-making. Applying generally accepted therapeutic, developing functions of musical art in the research of recreational music-making programme was aimed at interests and needs of different age group owing to the questionnaire method held at the beginning of the research. Fluctuating data of aesthetic culture level before and after the experiment were not pointed out in the material of the work because this programmme is not finished and active work is being held to develop this direction. However strong example of this method usage effectiveness is group's participating in concert performances in the wings of musical educational recreational course which was held in museums and galleries of Kazan city.
\end{abstract}

Keywords-personal aesthetic culture; musical art; cultural and recreation activity; instrumental music-making.

\section{INTRODUCTION}

Culture is the fundamental factor which identify man's behaviour and needs. Every person forms culture through learning and then learns through culture. In the process of growing-up a man acquire value system which characterizes his family and society, his needs are formed. These values and needs define person's consumer activity. At present time more attention is paid to the question of modern education tendency to professional knowledge and skills development on the basis of intellectual actions, very often neglecting other personal dimensions such as: emotions, feelings etc. In scientists point of view one of the main tasks of modern man's development is the development of the ability to enjoy the art and beauty and act according to the sense of proportion, harmony and beauty in his interior and external life. [4].
Center of aesthetical culture is art as activity bringing into world artistic and aesthetic values. In our research we refer to positions of well-known scientist L.S. Vygotsky inspired by the conception of $\mathrm{k}$ catharsis he reviews art as a method of avoiding and damaging contradictions of person's life; hence is a way of overcoming the emotions by generalized ways through esthetic form. Art must be concerned as a method of creating possible future activities for people. In other ways Vygotsky sees art not as an object of perception but as a way of creating person's own living conditions and in doing so creating himself..[6]. Referring this position we consider necessary to use musical art as a main way of aesthetical culture, as we hold to an opinion of a famous musical representative N.F.Findeisen "music is capable of hugging all kinds of art, in music only one can find everything and catch nothing - its like god" [7, c. 158]. It's a well known fact that to influence the emotional experience, feelings and delight of wonderful things in contradiction to our modern rationalized world every person needs the development of aesthetical culture. The most potential in developing the main aim of the research carry the programmes of recreaational activity, realized in time free from study/work. Thus the aim of the research is working out of musical culture-recreational programme through the example of music-making. It is supposed that the programme will be oriented on the different aged people taking into consideration age peculiarities, needs and interests. For the purpose realization the following research tasks were worked out: to define the part of leisure activity in development of personal aesthetic culture through the example of the programme of instrumental music making; referring the well-known opinion that music has a lot of socio-psychological influences and meanings for people in different periods of their development it's necessary observe the potential of musical art and study the most effective methods and techniques bringing along the achievements of aims; also being ruled by musical and pedagogical experience of the author work with different people authorial methods and techniques were being worked out. They bring along the development of personal aesthetical culture. 


\section{RESEARCH METHODOLOGY}

In experimental work with the group of 18 years old and older there wasn't a division into experimental and control groups, because among given respondents after attending several lecture courses there formed a group which wanted to attend classes in active form of art - instrumental musicmaking -9 people (5 youth group; 2 people- $60+, 1-$ teenager of 15 years old, "mini group"- parent ands child) for which there was used an additional space - private musical school «Easy music». Work with this group began in June 2018 up to present time.

Practical lessons in the scope of the project «Art Music Travel», which was held in Kazan there were organized series of musical educational lecture courses targeted audience of which were children and teenagers also the audience of different ages attending museums. Programme of the lectures course relied on the principle of synthesis of arts, which is the most effective in achieving the main aim of the research - development of musical-aesthetic culture of a person. Programme of the lecture courses included number of sections (directions) which contributed not only to achievement of the main aim of the research but encourage the person to active creative practices. The most effective and meaningful was the section of active musical activity which supposed elementary music-making on musical instruments (wind and percussion). As well people elder than 18 years old (students, adults and also elderly age $60+)$ has the interest in participating in this category. In consequence there formed a group which has the desire to continue music-making practice on a particular instrument (piano), for this experiment an area of private musical school was used, because at present time free musical education was affordable only for people under 18 .

In the wings of a person aesthetic culture development creative method of leisure music making, following methods were used:

information theoretic method- analysis, demonstration, (classroom evenings for non-professional performances were organized who attending systematical classes mastered basic skills and abilities making possible the demonstration of musical piece in public);

observation (team leader maintains a journal dynamic development of aesthetic culture observations by means of music-making according to each member);

practice-operation method (authorial methods of musical notation acquisition by the hand, practice of using of the application on iPad);

searching-creative methods (mutual performance of musical piece on a musical instrument (piano), that is practice of instrumental art acquisition in mini-groups (2 people));

educative method (stimulation method - (active participation in concert activity the members of the leisure instrumental music-making programme);

methods of culture and recreational activity (play, improvisation) - in the class of instrumental music making we make emphasis on the fact that instrumental play it's first of all "playing process", and to learn to play the instrument it's necessary to know certain rules, to gain the skills and teacher's task is to bring the students the process of new knowledge and abilities in the playing form;

information- psychological methods (persuasion, instillation)-great part of people showing the desire to play the instrument had the great deal of doubts and questions "will I get any luck?", "I don't have an instrument, so I can't", and such as "I also studied well, everything came naturally to me, but I couldn't get any luck at playing the instrument, though I wanted to", In these cases not only methods but also techniques of success infusion are necessary

In order to define the aims in the lessons of active creative practice on the instrument (piano), as well as reference to the research programme in the work method of social inquiry - questionnaire was used.

\section{RESULTS.}

Results of questionnaire revealed the aim of lessons with active creative practices on the instrument.

1 The youth group is represented by: - 1 mini-group, a young girl and a young man who wish to spend together an active creative leisure, and who also have a mutual aim to perform a musical piece in a wedding party in a year; - E.A. (26 years old, an interpreter) the aim at active creative practices - gaining new skills, performing on stage; - T.B. (30 years old, coach) - reviews active creative practices only from the point of view of art-therapeutic direction; L.A. (32 years old-engineer) -lessons of active creative practices, in the aim of self-development, gaining new skills. 2 Adult group is represented by a "mini-group.parent-child" in our case mother (Yu. S.) and a son (R.S., 8 years old), coeducation. The mother according to her words had bad experience in musical-aesthetic education. Lessons of active creative practices are reviewed with the purpose of increasing musical-aesthetic culture of the mother and child, as well as spending mutual leisure.

3 Group 60+: O.L. (57 years old, financial expert). Purpose is to learn to play the instrument, pick up favorite tunes, and also mutual performance with a granddaughter short musical pieces; F.N. (70 years old). The purpose is performing favorite tunes, performing on stage, wish to participate in contests of "music lovers". In the process of work special programme corresponding the functions of cultural and recreational activity was worked out for each group, which included authorial methods, techniques of instrumental music making represented in the game form, which were more acceptable for all groups which were not only educational but also informative (talks about national musical aesthetic heritage), therapeutic (using techniques of rythmotherapy, imagotherapy, visualization etc. techniques. Thus in the result of experimental work creative method of "instrumental music-making" proves its effectiveness in the development of aesthetical culture of a person, because thanks to using numerous methods and techniques the programme brought along not only technical acquisition of 
rudiments of music, but significantly enriched musical culture of the participants, that in its turn is the indicator of aesthetic.

The result of this group is the participation in programmes of "musical-educational lecture courses."

Unfortunately, in modern Russia additional musicalaesthetic education for adults is practically not developed. Musical school named after Rimsky-Korsakov in St.Petersburg since 1991 is the only establishment with the budget department for students elder than 17-18 years old.

In Europe, especially in Germany schools for adults Millions of different ages people take part in unprofessional music-making: in clubs, societies, churches, different organizations. In educational centers special musical courses for adults are organized, there also family educational centers for children and their parents.

\section{DISCUSSION}

Distinguishing the phenomenon of aesthetic culture, it's necessary to define its place in culture system. According to many scientists' opinions aesthetic culture can be represented as a subsystem of higher levels: artistic culture $i$ $\rightarrow$ intellectual culture $\rightarrow$ culture in general. Yu. U. FohtBabushkin[16], O.V.Larmin [8], « the core of aesthetic culture is defined by artistic culture underlining that it is artistic culture that having its own structure and relative independence is the indicator of level of culture of the society, and to a great extent defines its character [8, c.43]. Music as an integral art of an intelligent, artistic culture contains the values of a personal spirit. Its study in its sociocultural aspects in L.P.Shypovskaya opinion gives opportunity "to rule the processes of artistic life which carry in society as universal means of socialization of a modern person for purpose of maximum deliverance of his intellectual powers - for development and strengthening of a humanity intellectual culture in general» $[18$, c.3]. It's also important to note that music is a kind of art where artistic images take shapes of sounds. Sounds is a vibrations wave of a particular frequency, power of a definite kind causing different aesthetic emotional experiences dynamics of which always lead to the certain hormone and biochymical changes influencing the intensity of metabolic processes, respiratory system, tonus of brain and blood circulation. Unlike other kinds of art music turns in time, it's impossible to see it, to touch, it's necessary to listen, that requires a great amount of time, psychoemotional costs, having a great impact on person's state

Close correlation between music and aesthetic culture is described in T.V.Leontyeva's monography. The author considers that "under the influence of music aesthetic sense is formed as a core of valuable orientations in artistic picture of the world, ability of aesthetic contemplation and selfconcentration are developed" [9, c.63]. Aesthetic culture author represents as a system elements of which are aimed at improvement of personal development, and also regulator of relations between a person and the environment. Author considers the main elements in the system of aesthetic culture as follows: aesthetic values, aesthetic sense, aesthetic ideal, desire for aesthetic enjoyment, knowledge and education, aesthetic education and self-education, creating aesthetic values, aesthetic experience. In authors point of view activating all the components of the given structure are necessary for the development of a person's aesthetic culture.

Position of the work «Personal Aesthetic Values Development as the Basis for a Modern Musician's Spiritual Formation» authors', is close to our research, and as one of the leading components of aesthetic world they single out art which consist of creative consciousness, aesthetic ideal, aesthetic activity [1].

Review of the art presents the biggest interests to us as the given component is the indicator of aesthetically developed person. In the modern living conditions creative person becomes more and more highly-sought by society. Huge changes in different fields and dynamic bounce of technical progress in our country for the short period of time insistently demand from young generation qualities which let creatively and efficiently approach to any of its aspects [17]. Specialists single out the most significant skills of the XXI century which include so called four «C-s»: Communication, Cooperation, Creativity and Critical mind [10]. Every person is capable of thinking creatively, but unfortunately most of the people hold back this creative mind making mental barriers. In A.B.Khashaeva's point of view creative thinking is a special instrument which demands purposive education, development [17]. One of the key, developing components of the art is aesthetic activity. At present time given category move beyond the strict art activity, it is displayed in the spheres of production (as components of a process, so as results of activity, motives, intensions, all the material and cultural means have aesthetic characteristics. Naturally aesthetic activity is a creative activity. T.E Tyutyunnikova has described an interesting correlation of creative process and enjoyment. She considers that the main characteristics of enjoyment is self-expression, spontaneity, freedom, mobility, discovery, achievement, establishment of a contact. All this set of characteristics is applied to the art process as well; so creativity, spontaneity and enjoyment become nearly synonyms, having the same source - consciousness: the ability to play, act out a fantasy, behave spontaneously, create take the beginning from it. [13]. Kinds of creative activity are various, one of the most widespread is creative music-making, which lets the person play the instrument, sing, dance during music playing and do it with pleasure. Thus in creative process itself, in the active musical activity development of personal aesthetic culture comes. Hence, it is musical activity that is one of the main components of aesthetic culture which influence the other components of this structure.

Observing the main components of intellectually developed person it's necessary to note about a phenomenon of XXI century - mosaic thinking, that is characteristic of a growing generation, "generation $Z$ " [10]. In this phenomenon scientists single out negative and positive sides. Negative factors of "mosaic thinking" is difficulty concentrating, patience, hyperactivity, absence of the wish to remember etc. To not numerous positive qualities of 
mosaic thinking specialists refer quick reaction, taking the decisions, ability of a person to adjust to circumstances, that is a man who has mosaic thinking in some situations, such as quick making decisions can be in a valued position than a person with a conceptual thinking (verbal) supposing "by speed, ways and psychophisiological mechanisms of recycling of information slower than mosaic thinking but more complete" [10], however, there is an opinion "that one can't achieve much in carrier with mosaic thinking, but young people with such way of thinking are good executives, easy controlled"[10]. Thus we consider it's necessary on the basis of worked out methods to work out and apply methods which synthetize this types of thinking for successful life realization. A.D. Semenovich supposes that in primary school it's necessary to lay emphasis on subjects involving aesthetic education, that is etiquette lessons, performing art, eurhythmy, dance, music etc [10]. All these subjects should contain mastering drawing, writing, reading, counting and knowing the laws of nature. O.A.Staritsyna considers one of the most effective methods used in the processes of education is gamification (for instance educational video games). [12]. This position is supported by T.N.Lombina having worked out authorial method of children development in game subject matter[10]. Specialists marked positive dynamics in using oriental practices: concentration, attention training, meditation, breathing exercises, yoga. Referring the specific of piano playing, which set into motion all the 10 fingers, both brain hemispheres, peculiar features of musical piece performance on the instrument, that is: continuous eye contact for the musical material (note reading), control for the playing instrument for correct place of notes on the keyboard, constant intellectual process caused by the necessity of proper performance of musical piece (putting words together, compliance of dynamics, pickings, author's instructions), also empathy to the performed composition, because the performer should get across the composer's thought, using method of leisure music-making is the most actual in solving this problem. Observing the potential of recreational activity in the process of aesthetical culture development, it becomes obvious that the main pedagogical, educational tasks are to involve to the sphere of sphere "serious leisure" (R.Stabbins), as this kind of recitation as opposed to for instance "occasional, not serious" one has significant long term advantages: self-culture, self-growth, self-esteem increase, sense of achievement etc., as well as the result of action, perfection of the performance.[11, c. 46]

Thus, literature review in the wings of our research promoted effective recreational programme according to the person aesthetic culture development.

Implementation of leisure music-making programme it's a kind of return to cultural traditions of XVIII-XIX century. So home music-making organized in home living rooms, saloons etc. took one of the leading positions. In most of the cases lovers of art whose aim was enlightenment of public took part in these meetings.

In the result of the past and modern experience analysis maintaining the purpose of aesthetic culture development we analyzed and used modern techniques and methods which are promotive of the achievement of research's aim.

Owing to analysis of Germany amateur music-making [3], in organization of our experiment in Kazan, Russia elements of programmes were used which enjoy popularity, for example, family educational centers, which give the opportunity to educate to different generations, such as parent-child. This programme we broadened and in the practice of organization the direction of "mini-group" we used mutual education of "family couples","parent and child", and also variants "grandmother and grandson", "husband and wife". It's also necessary to note that the simultaneous work with parents and children, e.g. organizing mutual leisure time promotes in R.Sh.Ahmadieva's opinion development of trust between a parent and a child, it's especially actual in the work with parents and teenagers. [5].

In organization of the beginning stage of piano playing education, modern techniques were actively used (application on the Ipad), which let to become familiar with musical notation This technique is actual for those people who don't have the opportunity to get the instrument for the home work, also the technique of notes education by the hand, which promote better memorizing of notes on the staff.

In the work with people at the age of $60+$ and older for the preventive measures against Alzheimer decease expressive method of music-making was used. While working out effective techniques in the wings of given method we referred the research of Peter Janat about the existence of strong correlation of music and recollections which is called by the author "brain subscription" [14]. Thus, on the first lessons each member of the group made a list of the most vivid musical pieces which are connected with bright life recollections and which they wanted to learn to play.

It's necessary to note the final rates of the results are not pointed out in this work, as the experiment is still going on as well as taking of this group by leisure music-making that is the result of the author activity by "musical-educational course lecture", the aim of which is involving a person into active art practices.

\section{CONCLUSION}

Analysis of the domestic and foreign literature in the sphere of aesthetic culture, musical art, culture-recreational activity, pedagogy, psychology and also personal experience of the author promoted the solving of the research tasks, defining the necessity of the aesthetic culture of a person development for the full, intellectual formation of personality, personal fulfillment in musical art and culture recreational activity, for achievement of research's aim working out the musical culture-recreational programme, on the basis of instrumental music-making for development of a person aesthetic culture, methods and techniques of which taking into account the needs and interests of different ages people.

At the result of the research suggestions promoting 
DOI: $10.14526 / 2070-4798-2019-14-1-18-24$

further development of studied theme were formed. As a result, we consider that by analogy with art schools, which have groups of students older than 18 years old, in children musical schools and children art schools to create in Russian Federation budgetary department for students elder than 1718 years old. In the capacity of educational programmes to use additional general enrichments in the sphere of art for children and adults. (Federal law at December, 29 N 273-Ф3 "About education in Russian ", Chapter 10. Additional education, Article 75. Additional education for children and adults [15]); by analogy with successful experience of Germany in creating family centers, supposing musicalaesthetic education for children, adults and also people of elder age we offer to use this experience and realize it in culture-recreation establishments on a budgetary basis.

\section{References}

[1] Anufrieva N., Anufriev E. Korsakova I., Slutskaya I., Shcherbakova A. Personal Aesthetic Values Development as the Basis for a Modern Musician's Spiritual Formation. Mediterranean Journal of Social Sciences MCSER Publishing, Rome-Italy. 2015, vol. 6, 5.

[2] Leung CM, Lee G, Cheung B, Kwong E, Wing YK, Kan CS, Lau J. Karaoke therapy in the rehabilitation of mental patients. URL: https://www.ncbi.nlm.nih.gov/pubmed/9676147.

[3] Michael Dartsch Music education outside the state school system/ Deutsches Musik informations zentrum. 2011.

[4] Olga Denac The Significance and Role of Aesthetic Education in Schooling Creative Education. 2014, 5, pp. 1714-1719. URL: https://file.scirp.org/pdf/CE_2014110610064203.pdf.

[5] Ahmadieva R.Sh. Ethnocultural traditions as a resource of optimization of pedagogical functions of a modern family. Candidate's thesis. Kazan. 2006, 226.

[6] Vygotsky L.S. Psychology of art. 3d edition. M.: Art. 1986, 572.

[7] Kurmeeva N.K. Extracurricular forms of musical-aesthetic education...Newsletter of OSU. 2013, 7(156), pp. 153-159

[8] Larmin O.V. Aesthetic development and education of young. M.: Edition of Moscow State University. 1978, 325.

[9] Leontyeva T.V. Aesthetic culture of sutents in the context of transformation of modern Russian society. Kazan: Gran-Dan. 2004, 200.

[10] Lombina T.N., Yurchenko O.V. "Peculiarities of education of children with mosaic thinking". URL: https://cyberleninka.ru/article/n/osobennosti-obucheniya-detey-sklipovym-myshleniem\%20(1).pdf

[11] Lasbuk I.V. Strategies of behavior of consumers of culture products values, interests, typology. Sociology institute; National academy of science of Belorussia. Minsk: Belorussian science. 2017, 299.

[12] Staritsyna O.A. "Mosaic thinking vs education Who is to be blamed and what to do? URL: https://cyberleninka.ru/article/n/klipovoemyshlenie-vs-obrazovanie-ktovinovati-chto-delat

[13] Tyutyunnikova T.E. "To see music and dance poems: Creative music making, improvisation and law of existance. Edit. Stereotype. M.: Book House «LIBROKOM». 2014, 264.

[14] Williamson V. Music is we are. How music influence our brain, health and life as a whole. Edition in Russian language, translation into Russian language, typography. OOO «Mann, Ivanov and Ferber». 2016.

[15] Federal law of December, 292012 г. N 273-Ф3 "About education in Russian Federation", Chapter 10. Additional education Article 75. Additional education of children and adults. URL: https://www.zakonrf.info/zakon-ob-obrazovanii-v-rf/75.

[16] Foht-BabushkinYu.U,Artistic culture.:problems of study and rule. All-Union Research Institute of study of art. M.: Science. 1986, 235.

[17] Hashaeva A.B. Establishment of creative thinking of young people. URL: https://cyberleninka.ru/article/n/formirovanie-kreativnogomyshleniya-molodezhi.

[18] Alexsandr S. Kuznetsov. Russian Professor's meeting. Russian Journal of Physical Education and Sport. 2019, 14(1), pp. 17-22.
[19] Shipovskaya L.P. Music as a phenomenon of intellectual culture. Doctor's thesis. Moscow. 2005, 383. 